\title{
Prevalence of non Helicobacter pylori species in patients presenting with dyspepsia
}

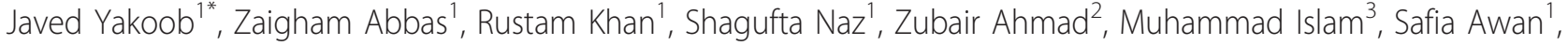
Fatima Jafri ${ }^{1}$ and Wasim Jafri ${ }^{1}$

\begin{abstract}
Background: Helicobacter species associated with human infection include Helicobacter pylori, Helicobacter heilmannii and Helicobacter felis among others. In this study we determined the prevalence of $H$. pylori and nonHelicobacter pylori organisms H. felis and H. heilmannii and analyzed the association between coinfection with these organisms and gastric pathology in patients presenting with dyspepsia. Biopsy specimens were obtained from patients with dyspepsia on esophagogastroduodenoscopy (EGD) for rapid urease test, histology and PCR examination for Helicobacter genus specific $16 \mathrm{~S}$ rDNA, H. pylori phosphoglucosamine mutase $(\mathrm{g} / \mathrm{mM})$ and urease B (ureB) gene of $H$. heilmannii and $H$. felis. Sequencing of PCR products of $H$. heilmannii and $H$. felis was done.

Results: Two hundred-fifty patients with dyspepsia were enrolled in the study. The mean age was $39 \pm 12$ years with males 162(65\%). Twenty-six percent (66 out of 250) were exposed to cats or dogs. PCR for Helicobacter genus specific $16 \mathrm{~S}$ rDNA was positive in 167/250 (67\%), H. pylori glmM in 142/250 (57\%), H. heilmannii in 17/250 (6\%) and H. felis in 10/250 (4\%), respectively. All the $H$. heilmannii and $H$. felis PCR positive patients were also positive for H. pylori PCR amplification. The occurrence of coinfection of $H$. pylori and $H$. heilmannii was $17(6 \%)$ and with $H$. felis was 10(4\%), respectively. Only one out of 66 exposed to pets were positive for $\mathrm{H}$. heilmannii and two for $\mathrm{H}$. felis. Histopathology was carried out in 160(64\%) of 250 cases. Chronic active inflammation was observed in 53(56\%) ( $p$ $=0.001)$ of the patients with $\mathrm{H}$. pylori infection alone as compared to $3(37 \%)(p=0.73)$ coinfected with $\mathrm{H}$. heilmannii and $H$. pylori and $3(60 \%)$ coinfected with $H$. felis and H. pylori $(p=0.66)$. Intestinal metaplasia was observed in $3(3 \%)(p=1.0)$ of the patients with H. pylori infection alone as compared to 2(25\%) $(p=0.02)$ coinfected with H. heilmannii and H. pylori and 1(20\%) coinfected with $H$. felis and H. pylori $(p=0.15)$.

Conclusion: The prevalence of $H$. heilmannii and $H$. felis was low in our patients with dyspepsia. Exposure to pets did not increase the risk of $H$. heilmannii or $H$. felis infection. The coinfection of $H$. pylori with $H$. heilmannii was seen associated with intestinal metaplasia, however this need further confirmation.
\end{abstract}

Keywords: Dyspepsia, gastric biopsies, H. pylori, H. heilmannii, H. felis, coinfection, cats, dogs

\section{Background}

Helicobacter species infect the gastrointestinal tracts of many animals from birds through humans. Some of these have been linked to a range of human diseases $[1,2]$ including chronic gastritis, peptic ulcer disease, mucosaassociated lymphoid tissue lymphoma, and gastric adenocarcinoma [1,3]. The principal Helicobacter infection in humans is Helicobacter pylori, with infection rates in developing countries reaching $50 \%$ to $90 \%[2,4]$. Human

\footnotetext{
* Correspondence: yakoobjaved@hotmail.com

'Department of Medicine, The Aga Khan University, Karachi, Pakistan

Full list of author information is available at the end of the article
}

gastric biopsy samples, however, have shown to harbor bacteria which were morphologically different from $H$. pylori $[5,6]$. These include Helicobacter heilmannii and Helicobacter felis which are primarily pathogens of domestic animals and were later found to infect humans as well [7-9].

Gastric non-Helicobacter pylori helicobacters constitute a diverse group of bacterial species that are known to colonize the gastric mucosa of several animals [10]. These include morphologically distinct, typically long spiral shaped bacteria originally referred to as Gastrospirillum hominis and later as $H$. heilmannii. The latter was
Ciomed Central

() 2012 Yakoob et al; licensee BioMed Central Ltd. This is an Open Access article distributed under the terms of the Creative Commons Attribution License (http://creativecommons.org/licenses/by/2.0), which permits unrestricted use, distribution, and reproduction in any medium, provided the original work is properly cited. 
further subdivided in two taxa, types 1 and 2 [10]. $H$. heilmannii type 1 are identical to $H$. suis which colonizes the stomachs of pigs. The former $H$. heilmannii type 2 represent a group of species, known to colonize the gastric mucosa of dogs and cats and include H. felis, $H$. bizzozeronii, $H$. salomonis, $H$. cynogastricus, $H$. baculiformis and a bacterium provisionally named in 2004 as "Candidatus $\mathrm{H}$. heilmannii" because at that time, it could not be cultured in vitro $[10,11]$. However, recently, in vitro cultures have been obtained resulting in description of H. heilmannii, as a novel Helicobacter species [12]. Sequencing of the $16 \mathrm{~S}$ or $23 \mathrm{~S}$ rRNA-encoding genes allows differentiation of $H$. suis from the other gastric non- $H$. pylori helicobacters species, but it cannot distinguish between $H$. felis, $H$. bizzozeronii, $H$. salomonis, H. cynogastricus, H. baculiformis and Candidatus $\mathrm{H}$. heilmannii [10]. For differentiation between these species, sequencing of the heat shock protein 60 (hsp60) or gyrase $\mathrm{B}$ (gyrB) gene is used while sequencing of the urease A and $B$ genes is considered to be the most suitable method since sequences of these genes are available $[10,11,13,14]$.

Dyspepsia describes a variety of symptoms, including abdominal pain, bloating, nausea, and vomiting. In these patients, endoscopy is considered to rule out gastroesophageal reflux disease, peptic or duodenal ulcer and gastric cancer. The role of $H$. pylori infection in dyspepsia remains controversial. This study aims to identify the prevalence of $H$. pylori and non-H. pylori helicobacters, $H$. felis and $H$. heilmannii and to analyze the gastric pathology associated with coinfection of these organisms in patients presenting with dyspepsia.

\section{Results and discussion}

Majority of the patients with $H$. pylori infection were in the age range of 18-39 years, while $H$. felis and $H$. heilmannii positive patients did not show this distribution. (Table 1). There was no difference in the gender, ethnicity of patients, crowding index $(\mathrm{CI})$ and source of water distribution among the patients with $H$. pylori and non- $H$. pylori infections (Table 1). All patients had abdominal pain with endoscopic gastritis as the predominant finding. The false positive and false negative results obtained with RUT were $15(36 \%)$ and $6(12 \%)$, respectively while with histology the false positive and false negative results obtained were $20(30 \%)$ and 10(11\%), respectively (Table $1-2$ ).

PCR for Helicobacter genus specific $16 \mathrm{~S} r D N A$ was positive in 167/250 (67\%), glmM (H. pylori) in 142/250 (57\%), H. heilmanii in 17/250 (6\%) and H. felis in 10/250 (4\%), respectively (Table 2).

PCR was positive for both $H$. pylori and $H$. heilmannii in $17(6 \%)$ and for H. pylori and H. felis in 10(4\%), respectively (Table 2). All the $H$. heilmannii and $H$. felis positive patients were also positive for H. pylori glmM PCR amplification (Table 2).
$26 \%$ (66 out of 250) were exposed to pets either cats or dogs. Most $H$. heilmannii positive patients did not have pet contact. Only one out of 66 exposed to pets was positive for H. heilmannii and two for H. felis (Table 3).

A higher degree of bacterial density was associated with H. pylori infection alone $(\mathrm{p}<0.001)$ (Table 1$)$. Chronic active inflammation was observed in 53(56\%) cases with H. pylori alone infection $(\mathrm{p}=0.001)$ compared to $3(37 \%)$ in H. heilmannii ( $\mathrm{p}=0.73$ ) and $3(60 \%)$ in $H$. felis positive patients coinfected with H. pylori $(\mathrm{p}=0.66)($ Table 1$)$. Intestinal metaplasia (IM) was present in 3(3\%) out of 94 cases with $H$. pylori infection alone compared to $2(25 \%)$ out of 8 cases of $H$. Heilmannii and $H$. pylori coinfection, and $1(20 \%)$ out of 5 cases of $H$. felis and H. pylori coinfection in which histology has been performed.

PCR product sequences were compared to the sequences of ureaseB of different $H$. heilmannii and $H$. felis strains. The H. heilmannii sequences had $100 \%$ similarity to 'Candidatus Helicobacter heilmannii' strains GenBank: AF508012 and L25079; while it was 99\% to GenBank: AY139170, AF507996, AY139172, AY139173 and 98\% to GenBank: AY139171, respectively. The H. felis sequences had $100 \%$ similarity to $H$. felis strains GenBank: FQ670179 and X69080; while it was 99\% to H. felis GenBank: AY368267, AY368261 and 98\% to GenBank: DQ865138, respectively.

Among our patients, the cohort exposed to pet animals was limited to $26 \%$. There were more patients with H. pylori infection who were in the 18-39 years age range. Such age distribution was not seen in cases with $H$. felis and $H$. heilmannii infection. There was no difference in the gender, ethnicity of patients, crowding index (CI) and source of water distribution among the patients with H. pylori and non-H. pylori helicobacter species infections. There were no statistically significant differences in the endoscopic findings in patients with $H$. pylori infection alone or with coinfection of $H$. pylori and non- $H$. pylori Helicobacter species. Chronic active inflammation was associated with $H$. pylori infection compared to $H$. heilmannii or H. felis coinfections with $H$. pylori (Table 1). However, the histology was not obtained in all the cases that showed $H$. heilmannii and $H$. felis infection. Intestinal metaplasia was present in 2(25\%) out of 8 cases of $H$. heilmannii coinfection with $H$. pylori and in $1(20 \%)$ out of 5 cases of $H$. felis coinfection with $H$. pylori as compared to $3(3 \%)$ of 94 cases with $H$. pylori infection alone who had undergone the histological study. Although it was not possible to draw a conclusion that IM was significantly associated with the coinfection of either of the species and $H$. pylori, a tendency in that way would be likely, as it has also been reported by other authors.

PCR positives at the species level were also positive for the Helicobacter genus specific 16S rDNA and all the H. heilmannii and $H$. felis positive patients were also 


\begin{tabular}{|c|c|c|c|c|c|c|c|c|c|}
\hline & \multicolumn{3}{|c|}{ PCR for H. pylori } & \multicolumn{3}{|c|}{ PCR for H. heilmannii } & \multicolumn{3}{|c|}{ PCR for $H$. felis } \\
\hline & Positive $n=142$ & Negative $n=108$ & $P$ value & Positive $n=17$ & Negative $n=233$ & $P$ value & Positive $n=10$ & Negative $n=240$ & $P$ value \\
\hline \multicolumn{10}{|l|}{ Age } \\
\hline 18-39 years & $81(57)$ & $55(51)$ & & $8(47)$ & $128(55)$ & & $6(60)$ & $130(55)$ & \\
\hline $40-55$ years & $53(37)$ & $35(32)$ & 0.02 & $7(41)$ & $81(35)$ & 0.82 & $3(30)$ & $85(35)$ & 0.93 \\
\hline $56-75$ years & $8(6)$ & $18(17)$ & & $2(12)$ & $24(10)$ & & $1(10)$ & $25(10)$ & \\
\hline \multicolumn{10}{|l|}{ Gender } \\
\hline Male & $98(69)$ & $64(59)$ & 0.11 & $11(65)$ & $151(65)$ & 0.99 & $5(50)$ & $157(65)$ & 0.33 \\
\hline Female & $44(31)$ & $44(41)$ & & $6(35)$ & $82(35)$ & & $5(50)$ & 83(35) & \\
\hline \multicolumn{10}{|l|}{ Ethnicity } \\
\hline Karachiite & $36(25)$ & $36(33)$ & & $4(24)$ & $68(29)$ & & $2(20)$ & $70(29)$ & \\
\hline Quetta resident & $47(36)$ & $31(25)$ & 0.15 & $5(29)$ & $73(31)$ & 0.81 & $3(30)$ & $75(31)$ & 0.75 \\
\hline Afghan & $55(39)$ & $45(42)$ & & $8(47)$ & $92(40)$ & & $5(50)$ & $95(40)$ & \\
\hline \multicolumn{10}{|l|}{ Crowding Index $(\mathrm{Cl})$} \\
\hline $0-1$ (low) & $59(41)$ & $39(36)$ & & $5(29)$ & $93(40)$ & & $5(50)$ & 93(39) & \\
\hline 2-4 (moderate) & $82(58)$ & $62(57)$ & 0.03 & $12(71)$ & $132(57)$ & 0.35 & $5(50)$ & 139(58) & 0.59 \\
\hline$>4$ (crowding) & $1(1)$ & $7(7)$ & & $0(0)$ & $8(3)$ & & $0(0)$ & $8(3)$ & \\
\hline \multicolumn{10}{|l|}{ Water supply } \\
\hline Municipal & $86(61)$ & $59(55)$ & 0.34 & $8(47)$ & $137(59)$ & 0.34 & $7(70)$ & 138(58) & 0.52 \\
\hline Boring Water & $56(39)$ & $49(45)$ & & $9(53)$ & $96(41)$ & & $3(30)$ & $102(42)$ & \\
\hline \multicolumn{10}{|l|}{ EGD } \\
\hline Gastritis & 136(96) & $106(96)$ & 0.47 & $17(100)$ & 225(97) & 1 & $10(100)$ & $232(97)$ & 1 \\
\hline Duodenal ulcer & $6(4)$ & $2(4)$ & & $0(0)$ & $8(3)$ & & $0(0)$ & $8(3)$ & \\
\hline \multicolumn{10}{|l|}{ Rapid Urease test $(n=90)$} \\
\hline Positive & $42(88)$ & $15(36)$ & $>0.001$ & $4(44)$ & $53(63)$ & 0.28 & $2(40)$ & $55(63)$ & 0.35 \\
\hline Negative & $6(12)$ & $27(64)$ & & $5(56)$ & $28(37)$ & & $3(60)$ & $30(37)$ & \\
\hline \multicolumn{10}{|l|}{ Histopathology $(n=160)$} \\
\hline \multicolumn{10}{|l|}{ Bacterial density } \\
\hline Occasional & $10(11)$ & $40(61)$ & & $3(37)$ & $47(31)$ & & $\mathrm{O}(0)$ & $50(32)$ & \\
\hline Few in some fields & $59(63)$ & $21(32)$ & $>0.001$ & $2(25)$ & $78(51)$ & 0.27 & $4(80)$ & $76(49)$ & 0.14 \\
\hline Only $1 / 2$ small clusters & $25(27)$ & $5(7)$ & & $3(38)$ & $27(18)$ & & $1(20)$ & 29(19) & \\
\hline \multicolumn{10}{|l|}{ Inflammation type } \\
\hline Chronic & $41(44)$ & $47(71)$ & 0.001 & $5(63)$ & 83(55) & 0.73 & $2(40)$ & $86(55)$ & 0.66 \\
\hline Chronic active inflammation & $53(56)$ & 19(29) & & $3(37)$ & $69(45)$ & & $3(60)$ & $69(45)$ & \\
\hline \multicolumn{10}{|l|}{ Lymphoid follicles } \\
\hline Positive & $14(15)$ & $8(12)$ & 0.73 & $0(0)$ & $22(14)$ & 0.30 & $0(0)$ & $22(14)$ & 0.47 \\
\hline Negative & $80(85)$ & $58(88)$ & & $8(100)$ & $130(86)$ & & $5(100)$ & $133(86)$ & \\
\hline \multicolumn{10}{|l|}{ Intestinal metaplasia } \\
\hline Positive & 3(3) & 2(3) & 1.0 & $2(25)$ & $3(2)$ & 0.02 & $1(20)$ & $4(3)$ & 0.15 \\
\hline Negative & $91(97)$ & 64(97) & & $6(75)$ & 149(98) & & $4(80)$ & $151(97)$ & \\
\hline
\end{tabular}


Table 2 PCR results for Helicobacter species

\begin{tabular}{lccc}
\hline & PCR for Helicobacter genus specific & 16SrRNA \\
\hline & Positive $\mathrm{n}=167$ & Negative $\mathbf{n}=\mathbf{8 3}$ & P value \\
\hline H. pylori glmM & & & \\
$\quad$ Positive & $133(80)$ & $9(11)$ & $<0.001$ \\
$\quad$ Negative & $34(20)$ & $74(89)$ & \\
H. heilmannii ureB & & & \\
$\quad$ Positive & $17(10)$ & $0(0)$ & 0.003 \\
$\quad$ Negative & $150(90)$ & $83(100)$ & \\
H. felis ure A and B & & & \\
$\quad$ Positive & $10(6)$ & $0(0)$ & 0.03 \\
$\quad$ Negative & $157(94)$ & $83(100)$ & \\
\hline
\end{tabular}

Univariate analysis was performed by using the independent sample t-test, Pearson Chi-square test or Fisher Exact test where appropriate. A P-value of $<$ 0.05 was considered as statistically significant. ${ }^{*}$ All the $H$. heilmannii and $H$. felis PCR positive patients were also positive for $H$. pylori PCR amplification.

positive for $H$. pylori glmM PCR (Table 2). PCR product sequences of ureaseB gene of $H$. heilmannii had shown $100 \%$ similarity to 'Candidatus H. heilmannii strains' GenBank: AF508012 and L25079; while H. felis sequences had shown $100 \%$ similarity to strains GenBank: FQ670179 and X69080.

In this study, we used urease gene-based PCR method developed by Nieger et al that detected only 'Candidatus H. heilmannii' DNA from pure in vitro cultures of other non-H. pylori helicobacter species [14]. This method was also used by other investigators to demonstrate the presence of Candidatus $\mathrm{H}$. heilmannii DNA in gastric biopsies from patients with dyspepsia $[11,15,16]$. The limitations of our study include the small number of patients who had non- $H$. pylori helicobacter infection and the presence of $H$. pylori co-infection which precluded assessment of the histological effect of these species under consideration. Also, the significance of coinfection in terms of disease development could not be determined. We could have identified few more cases of non- $H$. pylori helicobacter species by other reported methods used to study non $H$. pylori helicobacter species including fluorescent in situ hybridization (FISH), transmission electron microscopy (TEN) and partial $16 \mathrm{~S}$ ribosomal sequencing for analyses of the amplified products [12,17].

The implications of this study are that non- $H$. pylori helicobacter species infection occurs in patients with abdominal pain or discomfort similar to $H$. pylori infection. Most of our H. heilmannii infections were not associated with contact with animals. This is in contrast to a previous analysis of 125 patients with confirmed $H$. heilmannii infection that showed some $70.3 \%$ of the 111 patients had a history of contact with one or more animals $[17,18]$. All of our patients with non- $H$. pylori infection had endoscopic gastritis though their association with peptic ulcer is well known $[19,20]$. The prevalence of coinfection of $H$. felis with $H$. pylori in our population is less than what has been reported from South Africa among African population but is certainly higher than that for $H$. heilmannii and $H$. pylori from the northern Europe which showed that only $1.6 \%$ had concomitant infection with H. pylori $[20,21]$. The coinfection in our patients demonstrated severe gastric pathology, as intestinal metaplasia was present in $25 \%$ of $H$. heilmannii coinfection with $H$. pylori while in $20 \%$ of $H$. felis coinfection with $H$. pylori. This was also reported in previous studies [22]. In this study, the difference was not statistically significant due to the number of subjects in each group. The routine transmission of $H$. pylori appears to be human-human whereas non-H. pylori helicobacter species are transmitted by cats, dogs, etc [22]. Consequently, the prevalence of $H$. heilmannii is expected to be significantly higher in environment with less hygiene and higher physical exposure to animals. However, in our study there was a negative association with pet contact as the patients reported limited exposure to these animals. There is a need to look into other modes of transmission of these infections.

\section{Conclusion}

As non $H$. pylori Helicobacter species are capable of producing complications similar to $H$. pylori so the identification of these species may be of importance in patients with dyspepsia. However, our study fails to show any increased risk of infection with these organisms on exposure to pet animals and any additional complications associated with co-infection in patients infected with $H$. pylori.

\section{Methods}

\section{Study population}

Between September 2009 and February 2011, a total of 250 patients with abdominal pain or discomfort who attended the gastroenterology outpatient clinic at a tertiary care hospital in Karachi were enrolled. The mean age of these patients was $39 \pm 12$ years, (range 18-75) with males $162(65 \%)$ and females $88(35 \%)$. Of these, 136 (54\%) were in the age group of $18-39$ years, $88(35 \%)$ in the group of 40-55 years and $26(10 \%)$ in the group of $56-$ 75 years. Ethical approval for the study was obtained from the Aga Khan University Ethics Review Committee. Informed consent was taken for participation in the study. A complete socio-demographic questionnaire including determination of socio-economic status, educational level, ownership of the place of residence, number of rooms in the house, number of people living in the household beside siblings, source of water supply e.g. municipal water pipeline or bore water (ground water) and type of latrine in use, was obtained from the patients. A history of exposure of enrolled patients to cats and dogs was determined and a physical examination was carried out. Inclusion criteria were i) ambulatory adult 
Table 3 Association of Helicobacter species with pets

\begin{tabular}{|c|c|c|c|c|c|c|c|c|}
\hline \multicolumn{3}{|c|}{ PCR for H. pylori } & \multicolumn{3}{|c|}{ PCR for H. heilmannii } & \multicolumn{3}{|c|}{ PCR for $H$. felis } \\
\hline Positive $n=142$ & Negative $n=108$ & $P$ value & Positive $n=17$ & Negative $n=233$ & $P$ value & Positive $n=10$ & Negative $n=240$ & $P$ value \\
\hline
\end{tabular}

Pets

P.05

\begin{tabular}{|c|c|c|c|c|c|c|c|c|c|}
\hline Yes & $42(30)$ & $24(22)$ & 0.19 & $1(6)$ & $65(28)$ & 0.05 & $2(20)$ & $64(27)$ & 1 \\
\hline No & $100(70)$ & $84(78)$ & & $16(94)$ & $168(72)$ & & $8(80)$ & $176(73)$ & \\
\hline
\end{tabular}
Univariate analysis was performed by using the independent sample t-test, Pearson Chi-square
heilmannii and $H$. felis PCR positive patients were also positive for H. pylori PCR amplification. 
males and non-pregnant females; ii) age 18 years or older; iii) patients with upper GI symptoms including abdominal/epigastric pain or discomfort, postprandial abdominal distension, postprandial nausea and vomiting. Exclusion criteria included i) receiving treatment for H. pylori, concurrent or recent antibiotic use such as metronidazole, clarithromycin, amoxicillin, tetracycline, doxycycline and other cephalosporin, ii) histamine-2 receptor blocker or proton pump inhibitor therapy and bismuth compounds in the last four weeks; iii) patients with regular use of NSAID; iii) patients with severe concomitant disease and iv) patients with upper GI surgery. A crowding index with three categories was constructed by dividing the number of individuals per household by the number of the rooms used as bedrooms [23]. A participant's household crowding was defined as 'low' if they scored an index of 0-1.0, moderately-crowded were '2-4' and $>4$ were highly 'crowded'.

On EGD, 242(97\%) were found to have endoscopic gastritis (GS) alone while $8(3 \%)$ had duodenal ulcer (DU). Biopsy specimens from the gastric corpus and antrum were taken for rapid urease test (RUT) or histopathology for the diagnosis of H. pylori and DNA extraction for polymerase chain reaction (PCR) to amplify H. pylori, H. felis and $H$. heilmanii genes. Ninety patients (36\%) out of 250 had a RUT done while 160(64\%) out of 250 had histology and provided gastric biopsy specimen for the detection of Helicobacter species.

\section{Histopathology}

Biopsy specimens were stained with hematoxylin and eosin. Sections were examined by an experienced gastrointestinal pathologist blinded to the clinical details of the patients and graded according to the updated Sydney classification [24]. The bacterial density was graded from 0 to 3 ( 0 , absent or occasional; 1 to 3 , from few and isolated bacteria to colonies). The infiltration of gastric mucosa by mononuclear cells and polymorphonuclear leucocytes, atrophy, and intestinal metaplasia were graded as follows: 0 , none; 1 , mild; 2, moderate; 3 , marked. Chronic inflammation was defined according to an increase in lymphocytes and plasma cells in the lamina propria graded into mild, moderate or marked increase in density. Chronic active gastritis indicated chronic inflammation with neutrophilic polymorph infiltration of the lamina propria, pits or surface epithelium graded as $0=$ nil, mild $=<1 / 3$ of pits and surface infiltrated; moderate $=1 / 3-2 / 3$; and marked $=>2 / 3$. Gastritis was scored by total sum of grade of gastritis ( mild $=1$, moderate $=2$, marked $=3$ infiltration with lymphocytes and plasma cells) and activity of gastritis (mild $=1$, moderate $=2$, marked $=3$ infiltration with neutrophilic granulocytes) either in the antrum or in the corpus. Atrophy was defined as the loss of glandular tissue, with or without replacement by intestinal-type epithelium. Criteria for a true positive result was established with positive RUT or histology and 16S rDNA amplification.

\section{DNA Extraction}

DNA was extracted from biopsy samples by using a QIAamp DNA mini kit from QIAGEN (Hilden, Germany) according to the manufacturer's protocol. Extracted DNA was stored at $-70^{\circ} \mathrm{C}$ until required.

\section{Polymerase chain reaction}

PCR was performed using extracted DNA as the template to identify H. pylori, H. heilmannii and H. felis. Samples that were positive for Helicobacter genus 16S rDNA were subsequently analyzed with different sets of previously published primers (Table 4) which encode H. pylori phosphoglucosamine mutase $(g \operatorname{lm} M)$, H. heilmannii ureB and $H$. felis internal fragment of the ure $A$ and $u r e B$ genes, respectively $[14,21,25,26]$. PCR amplification was carried out in a total volume of $25 \mu \mathrm{l}$ containing $2 \mu \mathrm{l}$ of $2 \mathrm{mM}$ dNTPs, $1 \mu \mathrm{l}$ of $50 \rho \mathrm{mol}$ of each forward and reverse primer used before [14,25-27]. (synthesized by

Table 4 Oligonucleotide primers used in this study to amplify Helicobacter spp. gene fragments

\begin{tabular}{|c|c|c|c|}
\hline Gene & Sequence $\left(5^{\prime}\right.$ to $\left.3^{\prime}\right)$ & Amplicon size (bp) & Reference \\
\hline \multicolumn{4}{|l|}{ Helicobacter $16 \mathrm{~S}$ rRNA } \\
\hline C97 & GCT ATG ACG GGT ATC C & 400 & 18 \\
\hline C 98 & GAT TIT ACC CCT ACA CCA & & \\
\hline \multicolumn{4}{|l|}{ H. pylori glmM } \\
\hline F & GGATAAGCTITTAGGGGTGTTAGGGG & 294 & 19 \\
\hline$R$ & GCTTACTTTCTAACACTAACGCGC & & \\
\hline H. heilmannii ureB & & 580 & 14 \\
\hline $\mathrm{F}$ & GGGCGATAAAGTGCGCTTG & & \\
\hline $\mathrm{R}$ & CTGGTCAATGAGAGCAGG & & \\
\hline H. felis ure $A$ and $B$ & & 241 & 20 \\
\hline $\mathrm{F}$ & GTG AAG CGA CTA AAG ATA AAC AAT & & \\
\hline R & GCA CCAAAT CTA ATT CAT AAG AGC & & \\
\hline
\end{tabular}


MWG Automatic synthesizer, Germany), 2.5 unit of Taq DNA polymerase (Promega, USA), $2.5 \mu \mathrm{l}$ of $10 \times$ PCR reaction buffer, $3 \mathrm{mM}$ of $\mathrm{MgCl}_{2}, 2 \mu \mathrm{l}$ of DNA template containing $0.5 \mathrm{ng}$ of extracted DNA and total volume rounded to $25 \mu \mathrm{l}$ by double distilled water. The reaction was carried out in a Perkin Elmer 9700 thermal cycler (Massachusetts, USA). The amplification cycles for the different Helicobacter spp. gene fragments were: $94^{\circ} \mathrm{C}$ for $5 \mathrm{~min} ; 94^{\circ} \mathrm{C}$ for $1 \mathrm{~min}, 55^{\circ} \mathrm{C}-58^{\circ} \mathrm{C}$ for $1 \mathrm{~min}, 72^{\circ} \mathrm{C}$ for 60 $90 \mathrm{sec}(35 \mathrm{cycles}) ; 72^{\circ} \mathrm{C}$ for $5-7 \mathrm{~min}$. Positive and negative reagent control reactions were performed with each batch of amplifications. After PCR, the amplified PCR products were electrophoresed in $2 \%$ agarose gels containing $0.5 \times$ Tris/acetate/ethylenediaminetetraacetic acid, stained with ethidium bromide, and visualized under a short wavelength ultraviolet light source. DNA from $H$. pylori strains ATCC 43504, H. felis ATCC 49179 and $H$. heilmannii JF804941.1 was used as a positive control and sterile deionized water as the negative control. Diagnosis of each of the Helicobacter species infection was established when Helicobacter genus PCR for $16 \mathrm{~S}$ rDNA was positive along with a species specific PCR for H. pylori, H. heilmannii or H. felis. PCR product of $H$. heilmannii and $H$. felis were sequenced to further confirm individual infection. The specificity of $H$. pylori phosphoglucosamine mutase $(\operatorname{glm} M)$ and segment of urease B primers for $H$. heilmannii and $H$. felis has been demonstrated previously [14,21,25-27].

\section{Sequencing of PCR product and BLAST Query}

The DNA fragments amplified by $H$. felis and H. heilmannii PCRs were purified by Qiagen quick PCR purification kit (Qiagen, USA) and sequenced using both the forward and reverse primers (Table 4 ) to verify that they represented truly the $H$. felis and $H$. heilmannii ureB gene. Sequence analysis was performed by Macrogen (Seoul, South Korea). ClustalX was used to edit the sequences. The sequences were edited to a length of $488 \mathrm{bp}$ for H. heilmannii and $210 \mathrm{bp}$ for H. felis. Homology of the DNA sequences to published sequences was determined by using BLAST window on the National Center for Biotechnology Information (NCBI) site at http://www.ncbi. nlm.nih.gov/BLAST.

\section{Nucleotide sequence accession numbers}

The sequenced PCR products of H. heilmannii and H. felis obtained in this study have been deposited in GenBank under the following accession numbers: JF804941, JF804942, JF804943, JF804944, JF804945, JF815095, JF815096, JF815097 and JF815098. PCR product sequences were compared to the sequences of Urease B of $\mathrm{H}$. heilmannii sequences GenBank: AF508012, L25079.1, AY139171.0, AY139171.1 and H. felis strains ref GenBank: FQ 6701792, AY368267.1 and AY368261.1.

\section{Statistical Method}

Using software EPI Info and using 10\% prevalence in the study population [21] with $95 \%$ confidence level and a bound on error of $\pm 4 \%$ the estimated sample size was 217.

Results are expressed as mean \pm standard deviation for continuous variables (e.g., age) and number (percentage) for categorical data (e.g., gender, etc.). Univariate analysis was performed by using the independent sample t-test, Pearson Chi-square test and Fisher Exact test whenever appropriate. A $P$-value of $<0.05$ was considered as statistically significant. All p-value were two sided. Statistical interpretation of data was performed by using the computerized software program SPSS version 19.

\section{Acknowledgements}

This study was supported by the Higher Educational Commission Grant Ref: 20-1128/R\&D/09 to JY. We are grateful to laboratory stuff at the Juma Building at the Aga Khan University for their help during the conduct of this work.

\section{Author details}

${ }^{1}$ Department of Medicine, The Aga Khan University, Karachi, Pakistan. ${ }^{2}$ Department of Pathology, The Aga Khan University, Karachi, Pakistan. ${ }^{3}$ Department of Community Health Sciences, The Aga Khan University, Karachi, Pakistan.

\section{Authors' contributions}

$J Y$ conceived and designed the study, JY, ZAB, RK, WJ coordinated the study, $J Y, S N, F J$ did the work, JY and ZA analyzed the data, ZAH analyzed the histopathology, JY, MI, SA performed the statistical analysis. JY wrote the manuscript. All authors read and approved the final manuscript.

\section{Competing interests}

The authors declare that they have no competing interests.

Received: 3 May 2011 Accepted: 6 January 2012

Published: 6 January 2012

\section{References}

1. Fennerty M: Helicobacter pylori: why it still matters in 2005. Clevel Clin J Med 2005, 72(Suppl II):S1-S7.

2. Fox J: The non-H. pylori: their expanding role in gastrointestinal and systemic diseases. Gut 2002, 50:273-283.

3. Blanchard T, Eisenberg J, Matsumoto Y: Clearance of Helicobacter pylori infection through immunization: the site of $\mathrm{T}$ cell activation contributes to vaccine efficacy. Vaccine 2004, 22:888-897.

4. Jafri W, Yakoob J, Abid S, Siddiqui S, Awan S, Nizami SQ: Helicobacter pylori infection in children: population-based age-specific prevalence and risk factors in a developing country. Acta Paediatr 2010, 99:279-282.

5. Heilmannii KL, Borchard F: Gastritis due to spiral shaped bacteria other than Helicobacter pylori: clinical, histological, and ultrastructural findings. Gut 1991, 32:137-140.

6. Debongnie JC, Donnay M, Mairesse J: Gastrospirillum hominis (Helicobacter heilmanii): a cause of gastritis, sometimes transient, better diagnosed by touch cytology? Am J Gastroenterol 1995, 90:411-416.

7. Bunn J, MacKay W, Thomas J, Reid D, Weaver L: Detection of Helicobacter pylori DNA in drinking water biofilms: implications for transmission in early life. Lett Appl Microbiol 2002, 34:450-454.

8. Paster BJ, Lee A, Fox JG, Dewhirst FE, Tordoff LA, Fraser GJ, O'Rourke JL, Taylor NS, Ferrero R: Phylogeny of Helicobacter felis sp. nov, Helicobacter mustelae and related bacteria. Int I Syst Bacteriol 1991, 41:31-38.

9. Lee A, Hazell SL, O'Rourke J, Kouprach S: Isolation of a spiral-shaped bacterium from the cat stomach. Infect Immun 1988, 56:2843-2850. 
10. Haesebrouck F, Pasmans F, Flahou B, Chiers K, Baele M, Meyns T, Decostere A, Ducatelle R: Gastric helicobacters in domestic animals and nonhuman primates and their significance for human health. Clin Microbiol Rev 2009, 22:202-223.

11. O'Rourke JL, Solnick JV, Neilan BA, Seidel K, Hayter R, Hansen LM, Lee A: Description of "Candidatus Helicobacter heilmannii" based on DNA sequence analysis of $16 \mathrm{~S}$ rRNA and urease genes. Int J Syst Evol Microbiol 2004, 54:2203-2211.

12. Smet A, Flahou B, D'Herde K, Vandamme P, Cleenwerck I, Ducatelle R, Pasmans F, Haesebrouck F: Helicobacter heilmannii sp. nov., isolated from feline gastric mucosa. Int J Syst Evol Microbiol 2011, [doi: 0.1099/ ijs.0.029207-0].

13. Kivisto R, Linros J, Rossi M, Rautelin H, Hanninen M-L: Characterization of multiple Helicobacter bizzozeronii isolates from a Finnish patient with severe dyspeptic symptoms and chronic active gastritis. Helicobacter 2010, 15:58-66.

14. Neiger R, Dieterich C, Burnens A, Waldvogel A, Corthésy-Theulaz I, Halter F, Lauterburg B, Schmassmann A: Detection and prevalence of Helicobacter infection in pet cats. J Clin Microbiol 1998, 36:634-637.

15. van den Bulck K, Decostere A, Baele M, Baele M, Driessen A, Debongnie JC, Burette A, Stolte M, Ducatelle R, Haesebrouck F: Identification of nonHelicobacter pylori spiral organisms in gastric samples from humans, dogs, and cats. J Clin Microbiol 2005, 43:2256-2260.

16. Chisholm SA, Owen RJ: Development and application of a novel screening PCR assay for direct detection of 'Helicobacter heilmannii'-like organisms in human gastric biopsies in Southeast England. Diagn Microbiol Infect Dis 2003, 46:1-7.

17. Trebesius K, Adler K, Vieth M, Stolte M, Haas R: Specific detection and prevalence of Helicobacter heilmannii-like organisms in the human gastric mucosa by fluorescent in situ hybridization and partial $16 \mathrm{~S}$ ribosomal DNA sequencing. J Clin Microbiol 2001, 39:1510-1516.

18. Stolte M, Wellens E, Bethke B, Ritter M, Eidt H: Helicobacter heilmannii (formerly Gastrospirillum hominis) gastritis: an infection transmitted by animals? Scand J Gastroenterol 1994, 29:1061-1064.

19. Sykora J, Hejda V, Varvarovska J, Stozicky F, Gottrand F, Siala K: Helicobacter heilmannii-related gastric ulcer in childhood. J Pediatr Gastroenterol Nutr 2003, 36:410-413.

20. Dieterich C, Wiesel P, Neiger R, Blum A, Corthésy-Theulaz I: Presence of multiple "Helicobacter heilmannii" strains in an individual suffering from ulcers and in his two cats. J Clin Microbiol 1998, 36:1366-1370.

21. Fritz EL, Slavik T, Delport W, Olivier B, van der Merwe SW: Incidence of Helicobacter felis and the effect of coinfection with Helicobacter pylori on the gastric mucosa in the African population. J Clin Microbiol 2006, 44:1692-1696.

22. Meining A, Kroher G, Stolte M: Animal reservoirs in the transmission of Helicobacter heilmannii. Results of a questionnaire based study. Scand J Gastroenterology 1998, 33:795-798.

23. Conde-Glez CJ, Juárez-Figueroa L, Uribe-Salas F, Hernández-Nevárez P, Schmid S, Calderón E, Hernández-Avila M: Analysis of Herpes simplex virus 1 and 2 Infection in women with high risk sexual behavior in Mexico. Int J Epidemiol 1999, 8:571-576.

24. Dixon M, Genta R, Yardley J, Correa P: Classification and grading of gastritis-the updated Sydney system. Am J Surg Pathol 1996, 20:1161-1181.

25. Fox JG, Dewhirst FE, Shen Z, Feng Y, Taylor NS, Paster BJ, Ericson RL, Lau CN, Correa P, Araya JC, Roa I: Helicobacter species identified in bile and gallbladder tissue from Chileans with chronic cholecystitis. Gastroenterology 1998, 114:755-763.

26. Lu JJ, Perng CL, Shyu RY, Chen CH, Lou Q, Chong SK, Lee CH: Comparison of five PCR methods for detection of Helicobacter pylori DNA in gastric tissue. J Clin Microbiol 1999, 37:772-774.

27. Germani $Y$, Dauga C, Duval P, Huerre M, Levy M, Pialoux G, Sansonetti $P$, Grimont P: Strategy for the detection of Helicobacter species by amplification of $16 \mathrm{~S}$ rRNA genes and identification of $H$. felis in a human gastric biopsy. Res Microbiol 1997, 148:315-326.

\section{Pre-publication history}

The pre-publication history for this paper can be accessed here:

http://www.biomedcentral.com/1471-230X/12/3/prepub
doi:10.1186/1471-230X-12-3

Cite this article as: Yakoob et al:: Prevalence of non Helicobacter pylori species in patients presenting with dyspepsia. BMC Gastroenterology 2012 12:3.

\section{Submit your next manuscript to BioMed Central and take full advantage of:}

- Convenient online submission

- Thorough peer review

- No space constraints or color figure charges

- Immediate publication on acceptance

- Inclusion in PubMed, CAS, Scopus and Google Scholar

- Research which is freely available for redistribution 